sciforum

LAWSCI-01: Workshop on Challenges in Law, Technology,

Life, and Social Sciences, UPV/EHU, Bilbao, Spain, 2017

http://sciforum.net/conference/mol2net-03/lawsci-01

\title{
The imputability from the perspective of comparative law
}

\author{
Graciela García
}

\author{
Department of Basic and Criminal Law, Faculty of Law, \\ Central University of Las Villas (UCLV), Santa Clara, Cuba
}

\begin{abstract}
The topic of imputability has had a different approach in the different Codes of the world in accordance with the development of society and the well-known historical types of State and Law, each legal system possessing its legislative peculiarities, so that its assessment from the The perspective of comparative law offers us a more complete vision of it and the possibility of valuing different assessments through the prism of doctrinal and jurisprudence thinking. As Cobo del Rosal and Vives Antón point out: "Those who voluntarily place themselves in situations of unimputability to carry out the crime are already beginning their execution, and if that is the case, in the case of the actio liberae in causa dolosa, no there is a dissociation between the moment of action and the moment of imputability. " The basis of this idea falls on the statement of prominent jurists such as Von Lizst, Carrara and Maurach that indicate that knowingly placing oneself in a situation of unimpeachable means becoming an instrument of crime itself. In the same way that the imputable subjects use the unimputable to achieve their criminal purposes by becoming mediate authors, the former can also use themselves and commit crimes in the same way. The subject who is expressly placed in transitory mental disorder, is in fact catalyzing the illicit nature of their behavior. The free actions in their cause can be raised in the cases of drunkenness and sleep and they can not only be fraudulent but guilty, there are different criteria around their punishment being the most widespread which considers that these already exist at the beginning of execution of the conduct that is prosecuted. This does not mean that there are not many contrary opinions and arguments that the theory of actio liberae in causa can harm the principle of culpability and even legality, considering the need for the subject to be imputable also at the time of realization the fact. Thus, the impossibility of referring guilt to that moment has led to contradictions with dogmatic principles and various authors have pronounced in order to achieve a coordination between the above and the possibility of imposing a penalty. For its part, SAINZ CANTERO states: "The dominant doctrine is inclined in these cases to bring back the moment of the imputability to the one in which the cause was placed (the triggering action or omission), understanding that if in that time the subject of the action was imputable, we must have it as such, even if it were not, in the execution of the typical behavior ". However, in the opinion of BAJO FERNANDEZ: "The problem of coexistence between the theory of the actio liberae in causa and the dogmatic principles is only apparent." And to give grounds for this assertion, among other arguments, it refers to the fact that posed that there is a similar way of acting between the person who places a bomb and activating a certain mechanism makes it explode hours later and who "predisposes his own power of corporal action to act when the mind is in a state of unconsciousness". And continues: "Indeed this is so, but while the first assumption is explained because there is already a typical act of execution of the act to place the bomb, the second is not done with that circumstance, which requires an explanation of his punishment." Simply attending to reasons of material justice most of the legislations do not accept the exemption in such cases.
\end{abstract}

COBO DEL ROSAL, M Y VIVES ANTON, T.S.: Derecho Penal, parte general, quinta edición, Valencia, 1999, pág. 243. 
SAINZ CANTERO, J.A.: Lecciones de Derecho penal, Tomo III, parte general, Culpabilidad. Punibilidad. Formas de aparición, Madrid, 1985, pág.31

JAKOBS, G.: Derecho Penal. Parte General. Fundamentos y teoría de la imputación. Trad. Joaquín Cuello Contreras y José Luis Serrano González de Murillo, Madrid. 1995, pág. 630.

MIR PUIG, S.: Derecho penal, parte general, quinta edición, Barcelona, 1998, pág. 586.

MUÑOZ CONDE, F. y GARCIA ARAN, M.: Derecho penal, parte general, tercera edición, revisada y puesta al día conforme al Código penal de 1995, Valencia, 1998., pág. 389. 